Nemanja Tošković ${ }^{1}$, Danijela Rajić1, Ljubica Vasiljević1, Dragan Toškovićc ${ }^{*}$, Miloš Rajković ${ }^{2}$

1 University of East Sarajevo, Faculty of Technology, Zvornik, Bosnia and Herzegovina, ${ }^{2}$ University in Belgrade, Faculty of Agriculture, Zemun, Belgrade, Serbia

\author{
Scientific paper \\ ISSN 0351-9465, E-ISSN 2466-2585 \\ UDC: $543.4 / .5: 546.57 .59$ \\ doi: $10.5937 /$ ZasMat1801079T

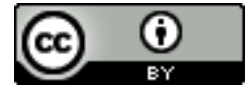 \\ Zastita Materijala 59 (1) \\ $77-81$ (2018)
}

\title{
Determination of $\mathrm{Au}$ and $\mathrm{Ag}$ from iron ores combining FA and ICP/AES methods
}

\begin{abstract}
In this paper, the combination of FA (Flame Analysis of Noble Metals - Cupellation) and ICP/AES (Atomic Emission Spectrometry with Induction Coupled Plasma) methods for determination of Au and $\mathrm{Ag}$ in geological samples of iron ore-magnetite was presented.Au and Ag were concentrated with $\mathrm{Pb}$ from $\mathrm{PbO}$ after desulphurisation and melting process $\left(\mathrm{Pb}^{2+} \rightarrow \mathrm{Pb}\right)$. Regulus $(\mathrm{Pb}$ with noble metals) is then cupellated. The resulting bead-pril after cupellation was dissolved in $\mathrm{HNO}_{3}$ and then in $\mathrm{HCl}$ (imperial water: $2 \mathrm{HNO}_{3}$ and $6 \mathrm{HCl}$ ). After the preparation of standard solutions and a blank test, the ICP/AES recording is performed. The obtained results werecompared with those obtained by the classical method of cupellation. The advantages of ICP/AES are excellent detection limits and linear dynamic range as well as a stable and repeating signal which is particularly important for samples of iron tested due to the low content of noble metals.
\end{abstract}

Keywords: geological samples, FA, ICP / AES, noble metals.

\section{INTRODUCTION}

Gold is found in small amounts in magnetite, pyrite and almost all ores silver, copper, beryllium, lead, zinc, telure and antimony. Due to the very heterogeneous composition of geological samples and the content of gold and silver in them no matter which method is used, their determination is carried out in two stages. First, it is necessary to separate the noble metals, $\mathrm{Au}$ and $\mathrm{Ag}$ from the sample of the ore by cupellation. After that $\mathrm{Au}$ and $\mathrm{Ag}$ are dissolved [1-5]. FA (flame analysis) of noble metals-cupellation is the oldest and very reliable method used for the determination of $\mathrm{Au}$ and $\mathrm{Ag}$ from metal ores $[6,7]$. In addition to the determination of $\mathrm{Au}$ and $\mathrm{Ag}$ from geological-mining samples wide application have extraction AAS analysis methods. This paper presents the possibility of determining $\mathrm{Au}$ and $\mathrm{Ag}$ by combining FA and ICP/AES methods. The ICP/AES method uses induced coupled plasma for the formation of excited atoms and ions that emit electromagnetic radiation at wavelengths characteristic in this case for Au and Ag.

\footnotetext{
${ }^{*}$ Corresponding author: Dragan Tošković

E-mail: tosked@ptt.rs

Paper received: 21. 09. 2017.

Paper accepted: 16. 11. 2017.

Paper is available on the website:

www.idk.org.rs/journal
}

The method provides the ability to determine the $\mathrm{Au}$ and $\mathrm{Ag}$ concentration of $\mathrm{ppb}$ [6-8]. By using this combined method, ppb detection values, linear dynamic range, low chemical interference and also a stable and repeating signal were determined $[9,10]$. In relation to our previous research, [1] in this paper for the FA/ICP AESpearl analysis imperial water $\left(2 \mathrm{HNO}_{3}: \quad 6 \mathrm{HCl}\right)$ was used.The amount of $\mathrm{PbO}$ in the stream was increased on $(40 \mathrm{~g})$ in order to obtain a higher regulusand higher accuracy. The amount of fluxes was reduced on $\left(\mathrm{Na}_{2} \mathrm{CO}_{3}(20 \mathrm{~g})\right.$, borax $\left.(10 \mathrm{~g})\right)$.

\section{EXPERIMENTAL PART}

\subsection{Preparation of sample for analysis by combining FA and ICP/AES method}

Ore's pieces were dried at $120^{\circ} \mathrm{C}$ for 60 minutes (before and after crushing) and then crushed on a mining crusher under a diameter of less than $3 \mathrm{~mm}$ and then into a mill with discs below $100 \mathrm{~nm} .20 \mathrm{~g}$ of the solid sample of iron ore was measured and placed in a furnace at a temperature of $600^{\circ} \mathrm{C}$ for $2 \mathrm{~h}$ to desulfurize. The sample is cooled and mixed in a shamotte cup with $40 \mathrm{~g} \mathrm{PbO}$, $20 \mathrm{~g} \mathrm{Na}_{2} \mathrm{CO}_{3}, 10 \mathrm{~g}$ borax, $3 \mathrm{~g} \mathrm{SiO}_{2}$ and $5 \mathrm{~g}$ starch. The prepared contents are placed in a melting furnace at $1070{ }^{\circ} \mathrm{C}$ for 1 hour. After the melting process is completed, the contents are poured into gray oil molds where, after cooling, a slag-rusty 
resin is formed. Formed $\mathrm{Pb}$ regulus with noble metals weighs $30-34 \mathrm{~g}[1,2]$. The slag is mechanically detached and the regulus is cleaned from mechanical impurities by forging. The cleaned regulus is subjected to the bathing process in bathing cups in charcoal baths first by heating up to the intake and putting them in a regulated position and at a temperature of $950^{\circ} \mathrm{C}$, continuing from 25-30 minutes by constant ventilation of the furnace. The bath containers adsorb part of the $\mathrm{Pb}$, other part evaporates so that after cooling, the beads of precious metals $\mathrm{Ag}$ and Au remain.

Since each $\mathrm{PbO}$ contains certain quantities of $\mathrm{Au}$ and $\mathrm{Ag}$, it is necessary to perform a blanktest sample- all except the sample.

\subsection{The dissolution process}

The bead is mechanically separated, purified as far as it is mechanically possible and subjected to the dissolution process by placing a bead of 150 $\mathrm{ml}$ glass and adding $2 \mathrm{~cm}^{3}$ concentrated $\mathrm{HNO}_{3}$ followed by $6 \mathrm{~cm}^{3}$ of $\mathrm{HCl}$ (imperial water $2 \mathrm{HNO}_{3}$ and $6 \mathrm{HCl}$ ) adding the acid to multiple portions to complete dissolution (at warm). After dissolution, the contents is transferred to a normal $100 \mathrm{ml}$ aliquot and supplemented with $20 \% \mathrm{v} / \mathrm{v} \mathrm{HCl}$. Aim is to leave silver in the form of complex salts of $\mathrm{AgCl}_{2}$ and $\mathrm{AgCl}_{3}$ remaining in solution. The precipitation is filtered through a teflonic filter of 0.45 . Before testing, a blank test is performed with all the acids except the sample.

All measurements were performed on ICP AES (Shimadzu 9820).

\subsection{Determination of gold}

Solutions for the calibration curve of gold were also prepared in two sets, the first $(1 ; 2 ; 4 ; 6 ; 8 \mathrm{ppb}$, $1 \mathrm{ppm} \mathrm{Au})$ and the other $(01 ; 02 ; 05 ; 0.8 ; 1.0 \mathrm{ppm}$ $\mathrm{Au})$. Gold was recorded at a wavelength of $242.795 \mathrm{~nm}$

\subsection{Determination of silver}

The calibration curves were made in two sets, the first $(0.1 ; 0.5 ; 1.0 \mathrm{ppm} \mathrm{Ag})$ and the other $(1 ; 2$; $4 ; 6 ; 8 ; 10 ; 15.20 \mathrm{ppm} \mathrm{Ag}$ ). A sample for a blank test and a dissolved sample were introduced into the system and the silver was recorded at an infrared length of $328,068 \mathrm{~nm}$.

\section{RESULTS AND DISCUSSION}

Experimental studies were carried out by determining the precious metal content $(\mathrm{Au}$ and $\mathrm{Ag}$ ) in geological samples of iron ore from previously prepared solutions. The results of the study were obtained by combining FA and ICP / AES method with FA method, under the same laboratory conditions. The FA (Flame Method for Determination of Noble Metal - Cupellation) is the oldest and most reliable method of determining precious metals from the ore but is a very long and expensive process. Due to the fact that gold is in nature in the form of quartz vessels, it is nonhomogeneously distributed in the iron ore. For this reason, a minimum sample size of $20 \mathrm{~g}$ is used according to our own experience and experience of other authors. Table 1 gives an overview of gold and silver content in $(\mathrm{g} / \mathrm{t})$ for seven samples and the standard deviation (s) obtained after five measurements using the FA method. Table 2 gives an overview of gold and silver content in $(\mathrm{g} / \mathrm{t})$ obtained by the FA / ICP AES method combination.

Table 1. Determination of gold and silver by cupellation (FA) [1]

Tabela 1. Određivanje zlata i srebra kupelacijom $(F A)[1]$

\begin{tabular}{|c|c|c|c|c|}
\hline \multirow[b]{2}{*}{ Sample } & FA & \multirow{2}{*}{$\begin{array}{c}\text { standard } \\
\text { deviation (s) }\end{array}$} & FA & \multirow{2}{*}{$\begin{array}{c}\text { standard } \\
\text { deviation (s) }\end{array}$} \\
\hline & $\begin{array}{c}A u \\
(g / t)\end{array}$ & & $\begin{array}{c}\mathrm{Ag} \\
(\mathrm{g} / \mathrm{t})\end{array}$ & \\
\hline 1 & 0,68 & 0,041 & 78,0 & 0,98 \\
\hline 2 & 0,50 & 0,032 & 61,0 & 0,87 \\
\hline 3 & 0,57 & 0,045 & 57,4 & 0,76 \\
\hline 4 & 0,46 & 0,023 & 49,8 & 0,34 \\
\hline 5 & 0,47 & 0,090 & 25,3 & 0,42 \\
\hline 6 & 0,18 & 0,003 & 20,2 & 0,28 \\
\hline 7 & 0,14 & 0,012 & 10,9 & 0,31 \\
\hline
\end{tabular}

Table 2. Determination of gold and silver combined method (FA and ICP / AES)

Tabela 2. Određivanje zlata $i$ srebra kombinovanom metodom (FA i ICP/AES)

\begin{tabular}{|c|c|c|c|c|}
\hline \multirow[t]{2}{*}{ Sample: } & $\begin{array}{c}\mathrm{FA} / \mathrm{ICP} \\
\text { AES }\end{array}$ & \multirow{2}{*}{$\begin{array}{l}\text { standard } \\
\text { deviation } \\
\text { (s) }\end{array}$} & $\begin{array}{c}\text { FA/ICP } \\
\text { AES }\end{array}$ & \multirow{2}{*}{$\begin{array}{l}\text { standard } \\
\text { deviation } \\
\text { (s) }\end{array}$} \\
\hline & $\mathrm{Au}(\mathrm{g} / \mathrm{t})$ & & $\mathrm{Ag}(\mathrm{g} / \mathrm{t})$ & \\
\hline 1 & 0,69 & 0,032 & 79,0 & 0,72 \\
\hline 2 & 0,50 & 0,024 & 62,0 & 0,62 \\
\hline 3 & 0,59 & 0,031 & 58,0 & 0,44 \\
\hline 4 & 0,47 & 0,017 & 50,0 & 0,35 \\
\hline 5 & 0,46 & 0,089 & 25,4 & 0,33 \\
\hline 6 & 0,19 & 0,003 & 20,1 & 0,24 \\
\hline 7 & 0,15 & 0,011 & 11,0 & 0,13 \\
\hline
\end{tabular}

Figures 1 and 2 show the calibrating curves used for $\mathrm{Au}$ and $\mathrm{Ag}$ with correlation coefficients and wavelengths.

The recording screens $\mathrm{Au}$ and $\mathrm{Ag}$ are shown in Figures 3 and 4 . On the recording screens in the right corner, you can see the interfering elements accompanying the precious metals. These elements are removed by process of preparation samples. 


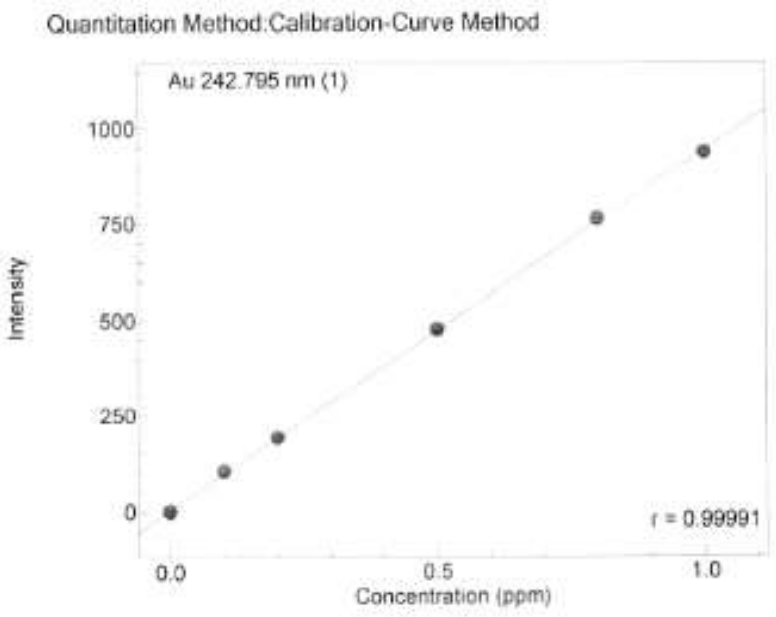

Figure 1. Calibration curve for gold

Slika 1. Kalibraciona kriva za zlato

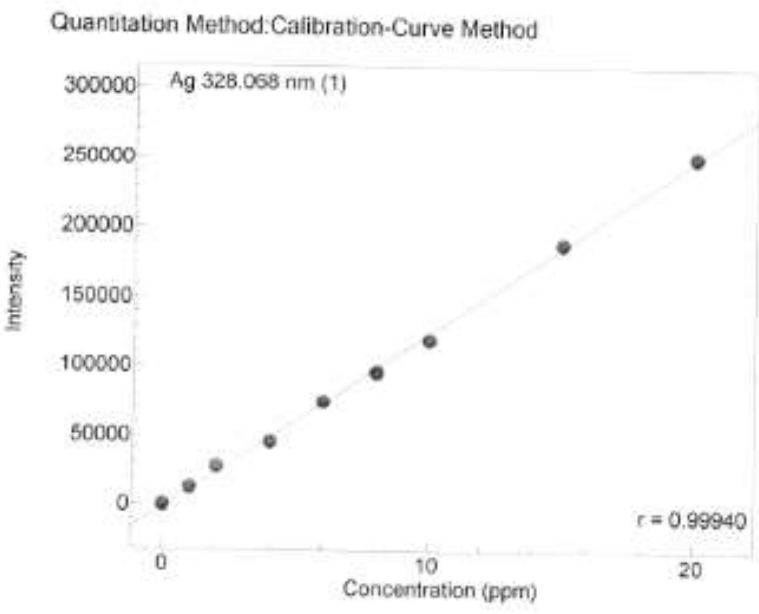

Figure 2. Calibration curve for silver Slika 2. Kalibraciona kriva za srebro

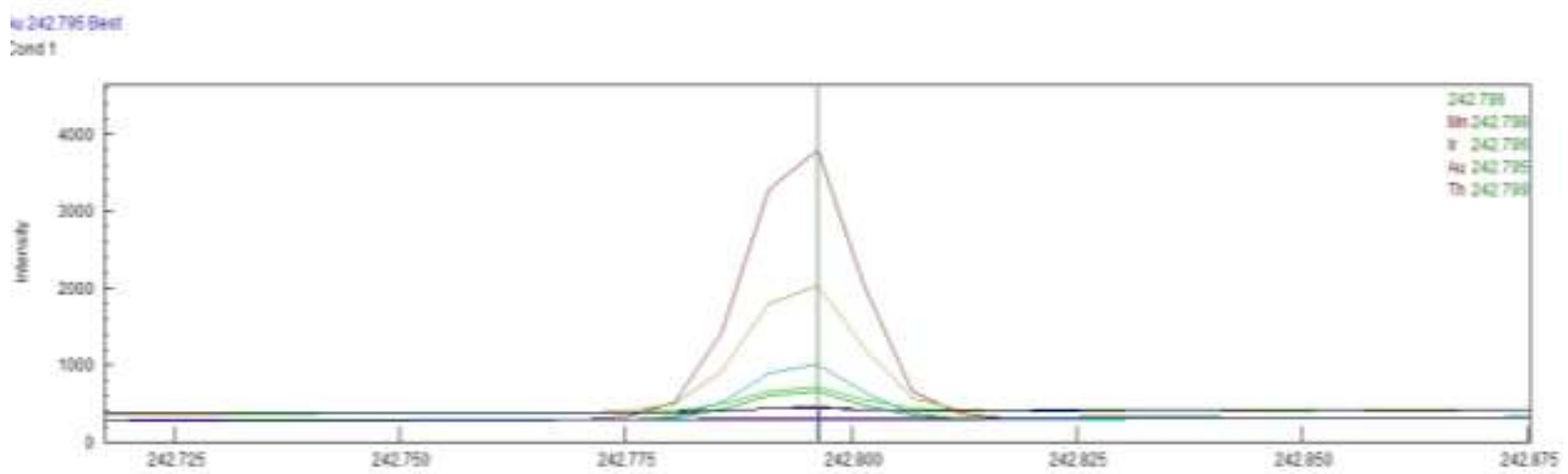

Figure 3. Spectrum of gold

Slika 3. Spektri zlata

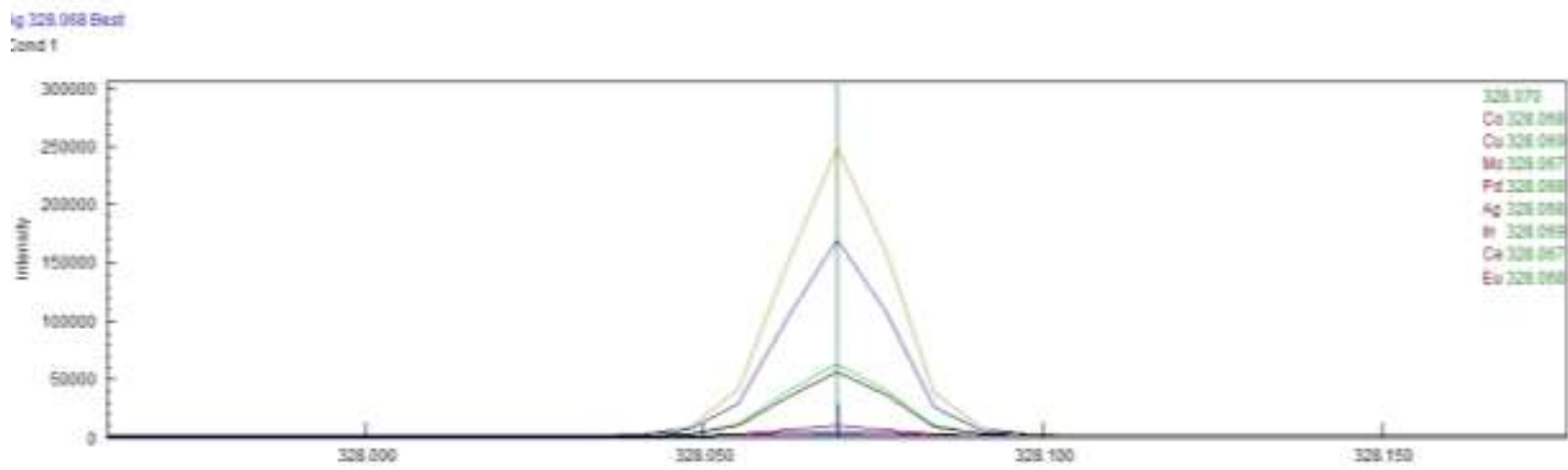

Figure 4. Spectrum of silver

Slika 4. Spektri srebra

Table 3 gives a summary of results obtained by comparing FA and FA / ICP AES methods. 
Table 3. Summary view of obtained results with differences

Tabela 3. Zbirni prikaz dobijenih rezultata sa prikazanom razlikom

\begin{tabular}{|c|c|c|c|c|c|c|}
\hline \multirow{2}{*}{ Sample: } & \multicolumn{2}{|c|}{ FA } & \multicolumn{2}{c|}{ FA/ICP/AES } & difference: & difference: \\
\cline { 2 - 7 } & $\mathrm{Au}(\mathrm{g} / \mathrm{t})$ & $\mathrm{Ag}(\mathrm{g} / \mathrm{t})$ & $\mathrm{Au}(\mathrm{g} / \mathrm{t})$ & $\mathrm{Ag}(\mathrm{g} / \mathrm{t})$ & $\mathrm{Au}(\mathrm{g} / \mathrm{t})$ & $\mathrm{Ag}(\mathrm{g} / \mathrm{t})$ \\
\hline 1 & 0,68 & 78,0 & 0,69 & 79,0 & $+0,01$ & $+1,0$ \\
\hline 2 & 0,50 & 61,0 & 0,50 & 62,0 & 0,00 & $+1,0$ \\
\hline 3 & 0,57 & 57,4 & 0,59 & 58,0 & $+0,02$ & $+0,6$ \\
\hline 4 & 0,46 & 49,8 & 0,47 & 50,0 & $+0,01$ & $+0,2$ \\
\hline 5 & 0,47 & 25,3 & 0,46 & 25,4 & $+0,01$ & $+0,1$ \\
\hline 6 & 0,18 & 20,2 & 0,19 & 20,1 & $+0,01$ & $-0,1$ \\
\hline 7 & 0,14 & 10,9 & 0,15 & 11,0 & $+0,01$ & $+0,1$ \\
\hline
\end{tabular}

\section{CONCLUSION}

A method for the rapid and accurate determination of $\mathrm{Ag}$ and $\mathrm{Au}$ was elaborated in geological samples of iron ore by atomic emission spectrometry with induced coupled plasma in combination with the cupellation. The bubbling method was efficiently separated and concentrated noble metals from the total mass of the sample, which allowed further dissolution processes in the respective acids to reliably determine their contents on ICP AES.

Correlation coefficients of calibration curves: Au $r=0.99991, \mathrm{Ag} r=0.99940$. Thickness of recording length: $\lambda(\mathrm{Au})=242,795 \mathrm{~nm} ; \lambda(\mathrm{Ag})=$ $328.068 \mathrm{~nm}$. The results obtained by the proposed method were compared to the results of analysis of the same samples by cupellation (FA) using $100 \mathrm{~g}$ $\mathrm{PbO}$ in the flux and for the FA / ICP analysis $40 \mathrm{~g}$ was used. The results are compatible, reliable and renewable as found in a number of experiments.

\section{REFERENCES}

[1] D.Rajić, N.Tošković, Lj.Vasiljević, D.Tošković, M. Rajković (2017) Određivanje Au i Ag iz rude gvožđa kombinovanjem FA i ICP/AES metoda, V International Congress Engineering, Ecology and Materials in processing Industry, Jahorina Mountain, Bosnia and Herzegovina.

[2] N.Petrović, D.Buđelan, S.Cokić, B.Nešić (2001) The determination of the content of gold and silver in geological samples, J. Serb. Chem. Soc., 66(1) 4552
[3] M.Balcerzak (2002) Sample digestion methods for the determination of traces of precious metals by spectrometric techniques, Analytical sciences, 18, 221-236

[4] F.R.Hartley (1991) Chemistry of the platinum group metals, Elsevier, Amsterdam

[5] L.C.Van Joon (1984) Accurate determination of the noble metals. Sample decomposition and methods of separation, Trends in Analytical chemistry, 3(10), 272-275

[6] Lj.Todorović, B.Anđelić, N.Petrović (2010) Determination of the content of gold and silver in ores, concentrates and tailings copper, Copper Institute, Bor, RS

[7] G.Zhang, M.Tian (2014) A rapid ICP-OES strategy for determination of gold and silver in blister copper by nitric acid digestion, Optics and Spectroscopy, 116(3), 365-367

[8] Y.Wang, L.A.Baker, I.D. Brindle (2016) Determination of gold and silver in geological samples by focused infrared digestion: A-re investigation of aqua regia digestion, The International Journal of Pure and Applied Analytical Chemistry, Talanta, Canada, p.421-423

[9] G.E. M. Hall, J. E.Vaive, J. A. Coope, E. F.Weiland (1989) Bias in the analysis of geological materials for gold using current methods, Journal of Geochemical Exploration 34(2), 157-171

[10] H.Shi, Z.P.Yang, J. H.Huang, Q.M.Zhou, C. X.Xiong (2009) Determination of trace elements in electrical absorption prospecting polyform sample by inductively coupled plasma mass spectrometry, Spectroscopy and Spectral Analysis, 29(6), 16871690. 


\section{IZVOD}

\section{ODREĐIVANJE Au I Ag IZ RUDE GVOŽĐA KOMBINOVANJEM FA I ICP/AES METODA}

$U$ ovom radu je prikazana kombinacija FA (plamena analiza plemenitih metala-kupelacija) $i$ ICP/AES (atomska emisiona spektrometrija sa indukovanom kuplovanom plazmom) metoda za određivanje Au i Ag u geološkim uzorcima rude gvožđa-magnetit. Au i Agse koncentišu sa Pb iz PbOnakon procesa odsumporavanja i topljenja ( $\mathrm{Pb}^{2+} \rightarrow \mathrm{Pb}$ ). Regulus ( $\mathrm{Pb}$ sa $\mathrm{Au}$ i Ag)se kupelira. Dobijena perla-pril nakon kupelacije se rastvara u $\mathrm{HNO}_{3}$ a zatim u $\mathrm{HCl}$ (carska voda $2 \mathrm{HNO}_{3}$ : $6 \mathrm{HCl}$ ). Nakon pripreme standardnih rastvora i blank probe vrši se snimanje na ICP/AES. Dobijeni rezultati su poređeni sa rezultatima dobijenim klasičnom metodom kupelacije. Prednosti ICP/AES su odlične granice detekcije i linearni dinamički opseg kao i stabilan i ponovljiv signal što je posebno bitno za uzorke ispitivane rude gvožđa zbog malog sadržaja plemenitih metala.

Ključne riječi: geološki uzorci, FA, ICP/AES, plemeniti metali

\section{Naučni rad}

Rad primljen: 21. 09. 2017.

Rad prihvaćen: 15. 11. 2017.

Rad je dostupan na sajtu: www.idk.org.rs/casopis

(C) 2018 Authors. Published by Engineering Society for Corrosion. This article is an open access article distributed under the terms and conditions of the Creative Commons Attribution 4.0 International license (https://creativecommons.org/licenses/by/4.0/) 